\title{
Valuation of Intellectual Property: A Review of Approaches and Methods
}

\author{
Harald Wirtz ${ }^{1}$ \\ 1 Fraunhofer Institute for Technological Trend Analysis, Euskirchen, Germany \& Hochschule Fresenius, \\ University of Applied Sciences, 50670 Cologne, Germany \\ Correspondence: Harald Wirtz, Fraunhofer Institute for Technological Trend Analysis, 53879 Euskirchen, \\ Germany, and Hochschule Fresenius, University of Applied Sciences, 50670 Cologne, Germany. E-mail: \\ harald.wirtz@int.fraunhofer.de
}

Received: September 26, 2011

Accepted: March 5, 2012

Published: May 1, 2012

doi:10.5539/ijbm.v7n9p40

URL: http://dx.doi.org/10.5539/ijbm.v7n9p40

\begin{abstract}
Intellectual property plays a crucial role in business performance and has become the central resource in almost all industries. This demands adequate methods for the valuation of IP. In valuation theory three basic approaches can be distinguished: cost approach, market approach and income approach. But these approaches can be applied to IP only to a limited extent. In this treatise approaches and specific methods for intellectual property valuation are examined and its applicability is critically discussed with a special interest on technical IP. Conditions, weaknesses and frontiers are shown and practical advice is given where possible.
\end{abstract}

Keywords: cost approach, market approach, income approach, direct cash flow method, relief from royalty method, multiperiod excess earnings method, incremental cash flow method

\section{Introduction}

While in earlier times plant or equipment were the most important assets for most enterprises, in younger days intellectual property (IP) is seen as the central resource for creating wealth in almost all industries. In knowledge-based economies IP plays a crucial role in business performance and economic growth. The market value of enterprises is based on their intellectual property to a large extent and the firms are managing these assets more actively to enhance their contribution to value creation (Kamiyama, Sheehan, \& Martinez, 2006; Hanel, 2006).

The term intellectual property includes patents, trademarks, copyrights, trade secrets and know-how. In this article special interest is given to IP with a technological basis such as patents and proprietary technology. A company that owns such IP has different possibilities of exploitation. It can either utilize it internally or make it available to other organizations by licensing or selling (Smith \& Parr, 2005). In addition IP can be used for example as bargaining chips in negotiations with other firms, as an equity contribution when founding or entering a company or as collateral for bank loans (Loop \& Lipfert, 2006). These means of using IP demand adequate methods for valuation. Corporate managers need to value IP for many reasons such as value based management, accounting or mergers $\&$ acquisitions. Thus academics and practitioners have tried to transfer and adjust the traditional valuation approaches to intellectual property (among others Anson, 1996; 2001; Anson \& Serrano, 2001; Beyer \& Mackenstedt, 2008; Damodoran, 1994; Hoffman \& Smith, 2002; IDW, 2007; Khoury, Daniele, \& Germerad, 2001; Mard, Hyden, \& Rigby, 2000; Moser \& Goddar, 2008; Park \& Park, 2004; Pitkethly, 1997; Razgaitis, 1999; Reilly \& Schweihs 1998; Smith \& Parr, 2005; Spadea \& Donohue, 2001; Stiroh \& Rapp, 1998; Tenenbaum, 2002). But intellectual property is quite different from most tangible assets. Due to this special character of IP, problems arise in the appraisal process and not every valuation approach is appropriate for the valuation of IP in the same way. In this article the main valuation methods for IP described in the current literature are reviewed and discussed critically.

Three basic approaches of valuation can be distinguished (Reilly \& Schweihs, 1998; Smith \& Parr 2005):

- the cost approach,

- $\quad$ the market approach and 
- the income approach.

Each approach comprises several methods, which are based on the same valuation principle but differ in their individual application. Basically every valuation method that can be found in literature, even if described as a "new method", is more or less founded on one or a combination of several of these basic approaches. Figure 1 gives an overview of the valuation approaches and the mostly used valuation methods.

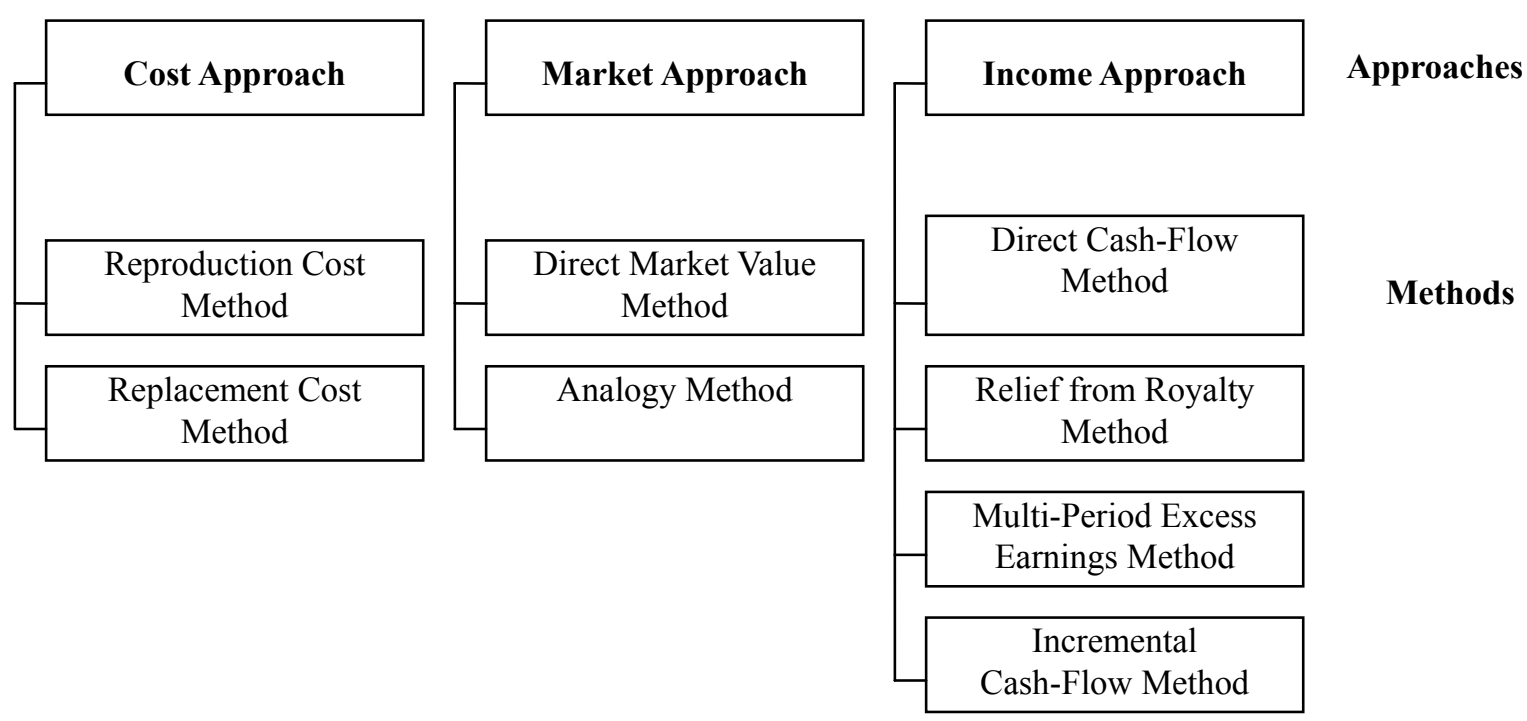

Figure 1. Valuation approaches and methods

Source: modified after IDW 2007, p. 66.

\section{Cost Approach}

The cost approach seeks to measure the value of a good by quantifying the cost for the substitution of the asset by another. The basic assumption of this approach is that the cost to build or buy new property equals the value of its ownership (Smith \& Parr, 2005). The reproduction cost method uses the cost of an exact replica, while the replacement cost method estimates the cost of the production or purchase of a good with an equivalent benefit. This means the asset must have the same utility but may be quite different in form and appearance. Because of the uniqueness of intellectual property an exact replica normally can not be created. So when using a cost approach it is more appropriate to use replacement costs in this context.

In practical application first the relevant cost elements have to be identified and estimated. These can be expenditures for labour or material as well as pure calculatory costs e.g. a calculatory interest for the capital employed (Jäger \&Himmel, 2003; Reilly \& Schweihs, 1998). Difficulties can arise from the appropriate assignment of indirect costs. In a second step a value reduction for technical or economic obsolescence has to be taken into account (Mard et. al., 2000).

An advantage of the cost approach is the easy possibility of collecting and processing the required data. Furthermore the approach is also applicable with partially completed IP, which normally is not bought or sold and does not generate any revenues (Hoffman \& Smith, 2002). But the approach has the crucial conceptual weakness that it does not really appraise the future benefits arising from the asset (Kamiyama, S., Sheehan, J., \& Martinez, 2006; IDW, 2007; Chiesa, Gilardoni, Manzini, \& Pizzurno, 2008). The underlying assumption that costs create value is very problematic in this context (Khoury, 2001; Boutellier, 2001; Woodward, 2002; Bittelmeyer, 2007). This is why these methods are rarely used in practice. When they are used, in many cases they serve as a plausibility check of values calculated by other methods (Mackenstedt, Fladung, \& Himmel, 2006).

In literature sometimes is stated, that the cost approach determines a minimum value, because no rational investor would pay more for an asset than the price of a property of the same utility, even if the value of the generated cash flow according to the income approach (see below) is higher (among others Anson, 2001; Moser \& Goddar, 2008; Beyer \& Mackenstedt, 2008). This is true without doubt, but also the other way round: No 
rational investor would pay more than the present value of the resulting cash flow, even if the cost approach would indicate a higher value.

\section{Market Approach}

The market approach is based on paid prices as an indicator for the value of an asset. The underlying principle is that under certain conditions supply and demand lead to an equilibrium in competitive markets (Reilly \& Schweihs, 1998).

The direct market value method seeks to use directly regarded transaction prices for the subject asset. This method requires an active market for the good, which means that the traded assets have to be homogenous, willing buyers and sellers can be found at any time and prices are publicly known (IDW, 2007). Intellectual property normally cannot match these requirements. Thus appraisers try to find transactions with comparable assets and to transfer the paid prices to the valuation object. This is called the analogy method. When comparable transactions are found, a common denominator or yardstick has to be found in order to calculate a multiplier for transferring the regarded prices to the appraisal object (Mard et al., 2000). Afterwards certain further adjustments can be necessary to take special market conditions, buyer motives or other distorting factors into account (IDW, 2005; Moser \& Goddar, 2008).

The biggest difficulty in the appraisal of intellectual capital can be seen in the appropriate choice of comparable transactions and suitable multipliers (Jäger \& Himmel, 2003; IDW, 2005; Kamiyama et al., 2006). For technological IP this can best be done by interdisciplinary teams of engineers or scientists and specialised economists. Information about market transactions can be retrieved by using specialized databases. But these can roughly reach completeness because the transaction conditions often are not available. In many cases IP is part of a bigger transaction, e.g. an acquisition of a whole company or a part of it. In these cases can hardly be said, which part of the paid price is granted for the IP.

But even if all these difficulties might be overcome, there remains a major problem for the usability of the market approach to appraise IP. The transaction object is by definition unique and the number of transactions is very limited. Thus it can be doubted that a concretely paid price can be seen as a real equilibrium price as stated above. Intellectual property is not a more or less exchangeable good like many tangible assets. In effect the market approach measures the value of the subject asset using somebody else's estimation of the value of a more or less similar asset. So in the end the appraisal is based on the hope, that those acting persons knew better than one self and that their estimations can be applied to the own valuation situation. This is the reason, why the market approach is recommendable for the valuation of IP only to a very limited extent. If it is used, high requirements are needed concerning choice and number of compared transactions and the way the prices are transferred to the valuation object. A detailed justification for the selection and the derived indices is essential.

\section{Income Approach}

The underlying theory of the income approach is that the value of property can be measured by the present value of the net economic benefit to be received over its life (Smith \& Parr, 2005; IDW, 2007). So the value of an asset is a result of its ability to generate cash flows and can be measured by the valuation of these cash flows. The cash flows can appear in different ways and depend on the possibilities of exploitation of the property. A patented technology for example can be used for the production of goods. The application of the technology can lead to cost savings or to higher quality, which allows higher prices and/ or an expansion of sales. But a patent can also be held without using it with the only purpose to prevent competitors from using a technology or entering a certain market. In all those cases the IP produces advantages in the market that allow higher prices and sales as well (Barton, 1998; Moser \& Goddar, 2008).

The future income flows in the coming years have to be discounted by an appropriate rate and summed (Discounted Cash Flow Method, DCF-Method). The resulting present value is the value that the object has from the view of its owner. This is the common way of an appraisal in investment theory. The discount rate represents in financial terms the comparison to an alternative investment. The present value is the amount that someone has to invest into the alternative for generating an equivalent series of cash flows.

Within the income approach different methods can be differentiated according to the way of determining the income flow (IDW, 2007):

- Direct Cash Flow Method,

- Relief from Royalty Method,

- Multiperiod Excess Earnings Method and 
- $\quad$ Incremental Cash Flow Method.

\subsection{Direct Cash Flow Method}

This method uses the cash flows that are directly attributable to the subject asset. A condition for this is that the cash flows can be measured directly. This will especially be the case if the technology is not used in production processes by the owner himself but is made available to third parties by licensing. The license fees can be used directly as cash flows in the valuation calculation (Beyer \& Mackenstedt, 2008). For example Fraunhofer as the developer of the mp3-technology does not manufacture any products using the technology. The patent family is exploited primarily through licensing agreements. The resulting license fees amount to high double-digit millions per year. They can be quantified relatively easily and with high reliability, at least for the near future.

\subsection{Relief from Royalty Method}

The idea of this method is that the income resulting from the ownership of the IP can be measured by the saved license fees, which would have to be paid, if the property would be licensed from another owner. The method requires that licensing agreements for similar assets can be monitored and transmitted. Therefore the method shows a clear proximity to the market approach and is even assigned to that approach by some authors (e.g. Reilly \& Schweihs, 1998) or called a hybrid approach by others (e.g. Anson \& Suchy, 2005). Just like the market approach one of the biggest problems of this method is the availability of information on such transactions. A number of commercial suppliers offer extensive databases for this purpose. These sources, however, often show significant differences and offer little additional information on the specific terms of the contracts (Beyer \& Mackenstedt, 2008).

Historically, many different methods have been used to identify royalty rates ranging from the sole discretion of the company CEO or corporate attorney (Sullivan, 1994), over a variety of rules of thumb (Parr, 1997) to analytic approaches based on litigation (Lee, 1992)

The fictive license fees are often derived on the basis of license rates based on certain parameters like for example revenues. If such a license rate is known, the planned sales, which are attributable to the subject property, can be multiplied by the license rate (IDW, 2007). Indeed in some industries or market segments something like "usual" license rates can be seen as a rule of thumb and are the starting point and basis of specific licensing negotiations. A popular example may be the so-called $25 \%$ rule. According to this rule, the licensee has to pay $25 \%$ of the expected profits from the product that requires the IP to the licensor (Goldscheider, Jarosz, \& Mulhern, 2002; Moser \& Goddar, 2008). If, for example the expected profit of the product based on sales and cost planning is $16 \%$, the license rate could be agreed upon $4 \%$ of the net sales. Despite (or perhaps because of) its crude simplicity this rule appears to be wide spread in some industries until recent times (Moser\& Goddar, 2008).

Because of the proximity to the market approach the relief from royalty method meets the same difficulties as described above. However, one can assume that the available data base on license agreements is better and more extensive than on purchase transactions. Thus the estimation of market license fees can succeed rather than the direct determination of market prices by singular purchase transactions. Furthermore, one can argue that even if license rates can be determined, the forecast problem is merely shifted to the level of sales and cost planning. This, however, is already part of the usual business planning and can be done by the usual procedures and tools used in the company. Anyway the assessment of the intellectual property will be consistent to business planning (Wirtz, 2010).

\subsection{Multi Period Excess Earnings Method}

Since intellectual property generates cash flows regularly only in combination with other assets, financial planning is typically done for such combined units. The multi period excess earnings method tries to isolate the cash flows attributable to the IP by deducting fictive fees (contributory asset charges) for all other assets from the entire cash flow of the unit (IDW, 2007). Those charges can be seen as rent or leasing fees for the use of those assets. So the multi period excess earnings method uses the opposite way of the relief from royalty method. While that method calculates fictive fees for the IP, the multi period excess earnings method calculates fictive charges for all other assets. Therefore Mackenstedt, Fladung and Himmel (2006) see the multi period excess earnings method as a grouping of the valuation problems of all other methods. When calculating the fictive leasing fees, on the one hand the value of the consumption (return of asset) and on the other hand a reasonable rate of return on the capital employed (return on asset) has to be taken into account (IDW, 2007). The identified contributory asset charges then have to be subtracted from the cash flows relative to the extent they are used for generating the income. It is another difficulty to find appropriate yardsticks for this purpose. 
In practice often for simplicity the EBITDA, the EBIAT or the EBIT are used instead of direct cash flows. EBIT and EBIAT already include depreciations of the assets. In order to avoid double counting these key figures have to be modified (Mackenstedt et al., 2006). According to my opinion it is anyway more recommendable to plan on the basis of direct cash flows (payments). This corresponds to a consistent application of the present value approach and leads - assuming same quality of planning - to more accurate results. This way also the danger of double counting is avoided automatically (Wirtz, 2010).

The multi period excess earnings method should always be reserved for the intellectual property that has the largest impact on the cash flows, so that the charges to be deducted really relate only to assets with a supporting character (IDW, 2005). Otherwise the bandwidth of assessment would be too large.

\subsection{Incremental Cash Flow Method}

The incremental cash flow method seeks to value the benefit of IP by comparing the income of the considered unit with the property to a situation without it. The difference between the cash flows for each period in the two situations shows the additional cash flow that is attributable to the asset being valued (IDW, 2007). This additional cash flow can result for example from achievable higher prices, higher sales volumes or cost savings in production. An essential condition for the application of the method is the possibility of a reliable estimation of the differences in price, quantities and costs that are caused by the intellectual property (Jäger \& Himmel, 2003; Mackenstedt et al., 2006).

\subsection{Discount Rate}

The expected annual cash flows have to be capitalized by a discount rate that is appropriate with respect to time and risk. For the determination of this specific rate often the cost of capital of the company is used as a basis and then adjusted to individual circumstances of the valuation object. If the assessment is for purposes of accounting, the derivation of the cost of capital from capital market data is recommended (IDW, 2007). This proceeding can also be useful for other assessment occasions, at least as a starting point for the further determination of the specific rate (Beyer \& Mackenstedt, 2008). In this context normally the concept of weighted average cost of capital (WACC) is used (Bäzner \& Timmreck, 2004; Schmusch \& Laas, 2006). The cost of capital thus can be determined following the formula (Brealey \& Myers, 2007)

\section{with}

$$
r_{W A C C}=r_{E} \cdot \frac{E}{C}+r_{D} \cdot(1-t) \cdot \frac{D}{C}
$$

$\begin{array}{ll}r_{\text {WACC }} & \text { weighted average cost of capital } \\ r_{E} & \text { cost of equity } \\ r_{D} & \text { cost of debt } \\ t & \text { tax rate } \\ \text { E } & \text { market value of equity } \\ D & \text { market value of debt } \\ C & \text { market value of total capital. }\end{array}$

For the evaluation situations considered here usually a constant capital structure is assumed. This way the circularity problem known from corporate valuation is avoided, which occurs from the fact, that the WACC influences the market value of equity and this value determines the WACC (Mandl \& Rabel, 1997; Drukarczyk $\&$ Schüler, 2009). Depending on the assessment purpose it can be favorable to use a peer groups capital structure and cost of capital rather than individual ones (IDW, 2007). The cost of debt has to be multiplied by the factor (1-t), because it is deductable from the income for tax purposes. The integration of taxes into the calculation is shown more detailed in the next section as a subject of its own.

The cost of equity is usually calculated on the basis of the Capital Asset Pricing Model (CAPM). According to this it can be calculated as

$$
r_{E}=i+\beta \cdot\left(r_{M}-i\right)
$$

with

i risk free interest rate

$r_{M} \quad$ rate of return of thee market portfolio

$\beta \quad$ beta-factor. 
The risk free interest rate is the starting point of the calculation. It is a mere theoretical value and can in practice be approximated by the interest rate of government bonds of financially solid states (Kruschwitz, 2005; Freiberg \& Lüdenbach, 2005). This basis rate then is increased by a risk premium. Therefore the so called market risk premium is multiplied by the beta factor. The market risk premium is the difference between the risk free interest rate and the yield of the market portfolio in the CAPM. This yield is a theoretical value as well. It stands for the rate of return of capital that an investor gets with a fully diversified portfolio of all risky investments traded on the market. In practice it is often estimated by using the rate of return of a broad index (Mandl \& Rabl, 1997; Kruschwitz, 2005). The risk premium is typically in the range of $4-5 \%$ (AKU, 2005).

The beta factor is a measure for the systematic risk of the valuation object, i.e. the risk that can not be reduced any more by diversification. It is calculated by dividing the covariance of the expected return of the valuation object and the market portfolio in the numerator and the variance of the expected returns of the market portfolio in the denominator. The beta factor shows the change of the return of the valuation object when the return of the market changes. With a beta larger (smaller) than one the expected rate of the valuation object reacts stronger (weaker) than the whole market (Mandl \& Rabl 1997). A clue for estimating the beta factor can be obtained from an analysis of historic rates of return. As a basis can be considered on the one hand the company itself (if such date is available) but on the other hand also a single company of reference (pure play beta), a group of companies (peer group beta) or selected sectors (industry beta) (Freiberg \& Lüdenbach, 2005; Lienau \& Zülch; 2006). After the weighted cost of capital have been identified for the whole company they have to be adjusted in a second step to the specific risk of the IP. In general one can assume, that the asset specific risk of such intangibles is higher than of many material assets such as plant, equipment or inventories. Currently a theory-based methodology for the identification of specific increases or reductions is lacking. This necessarily implies an unavoidable margin of appreciation (Castedello, Klingbeil, \& Schröder, 2006).

But the method described has more problems from the perspective of financial and economic theory. As obvious as the estimation of capitalization rates from capital market data by using the CAPM may be at first sight, it must not be ignored that a model with relatively strict application premises is used in a context, where these premises are not nearly given. In particular the CAPM is - at least in the applied basic form - a single period model (Sharpe, 1964; Lintner, 1965; Mossin, 1966). Its results can not be transferred automatically to the multi period case. Nevertheless the calculation of capital cost by using the CAPM in the context of discounted cash flow methods has meanwhile become an often used standard procedure.

\subsection{Consideration of Taxation in the Valuation}

Normally an assessment in the present value approach is made after taxes, which means that after-tax-cash-flows have to be discounted by after-tax-discount-rates. This principle follows from the fact that revenues from intellectual capital typically are subject to taxation. For this purpose most appraisers calculate the taxes on the basis of the cash flow in a first step and determine a tax amortization benefit (TAB) in a second step. This TAB results from the fact, that normally the amortization of the intellectual capital leads to a reduction of the taxable income and thus leads to a corresponding tax saving. The basis for the amortization is the value of the subject intellectual capital. Therefore we have again a circularity problem. This can either be solved iteratively or by the derivation of a so-called step-up-factor by which the present value without TAB is multiplied. In practice the application of a step-up-factor is the more usual way (Mackenstedt et al., 2006). Generally it can be calculated by using the following formula (see for the derivation Beyer \& Mackenstedt, 2008):

$$
\text { step }- \text { up }- \text { faktor }=\frac{1}{1-s \cdot \sum_{n=1}^{N} \frac{A F_{n}}{\prod_{n^{*}=1}^{n}\left(1+r_{W A C C_{n^{*}}}\right)}}
$$

with

$\mathrm{n}, \mathrm{n}^{*} \quad$ year

$\mathrm{N} \quad$ Amortization time

$\mathrm{AF}_{\mathrm{n}} \quad$ Amortization factor for the year $\mathrm{n}$.

In case of linear amortization and constant discount rates it can be simplified to 


$$
\text { step }- \text { up }- \text { factor }=\frac{1}{1-\frac{s}{N} \cdot \frac{1-\left(1+r_{W A C C}\right)^{-N}}{r_{W A C C}}}
$$

\section{Fazit}

Intellectual property (IP) is a factor of paramount importance to economic success. It generates value in many ways and is therefore a key resource in almost all industries. For an active management of IP adequate methods of valuation are required. With its cost, market and income approach valuation theory offers three basic approaches, which are essentially applicable for IP as well. But due to the fact that intellectual property is quite different from other assets, difficulties in the application of these traditional methods arise.

The cost approach is relatively easy to process but has the conceptual weakness, that it does not appraise the benefits of the IP but its cost. The market approach has the problem that comparable transactions are difficult to find and concretely paid prices can hardly be seen as real equilibrium prices. The income approach appears to be the most appropriate approach for many appraisal situations. Depending on the special circumstances of the appraisal situation different methods within this approach can be reasonable. At any rate there remain wide scopes for discretion. Therefore it is recommendable to use not only one method but to verify the results of a valuation by alternative methods.

The choice of the concrete valuation approaches and methods depends on the cause and purpose of a specific valuation situation. For an appropriate valuation it is crucial, that the application of the described methods is combined with the professional experience of the appraiser. Like in any valuation sensitivity is important. The proper application of a method and the knowledge about its borders and weaknesses may help to let sensitivity not become arbitrariness.

\section{References}

Anson, W. (1996). Establish market value for brands, trademarks and marketing intangibles. Business Valuation Review, 15 (2), 47-56.

Anson, W. (2001). Traditional Valuation Methodologies of Intellectual Property. The Licensing Journal, September 2001, 30-32.

Anson, W., \& Serrano, M. (2001). Intangible Asset Valuation Techniques. The Licensing Journal, January 2001, $37-38$.

Anson, W., \& Suchy, D. (2005). Intellectual Property Valuations. Chicago, IL: American Bar Association.

AKU (2005). Arbeitskreis Unternehmensbewertung (AKU) beim IDW: 84. Sitzung des AKU. Eckdaten zur Bestimmung des Kapitalisierungszinssatzes im Rahmen der Unternehmensbewertung. Fachnachrichten des IDW 2005, 70 -71.

Barton, J. (1998). Competition and competitive use of intellectual property. In: Barton, J., Brest, P., Lemley, M.: Stanford Workshop on Intellectual Property and Industry Competitive Standards 98. Stanford Law School.

Bäzner, B., \& Timmreck, C. (2004). Die DCF-Methode im Überblick. In: Richter, F./Timmreck, C. (Ed.). Unternehmensbewertung - Moderne Instrumente und Lösungsansätze(pp. 3-20). Stuttgart: Schäffer Poeschel.

Beyer, S., \& Mackenstedt, M. (2008). Grundsätze zur Bewertung immaterieller Vermögenswerte (IDW S 5). Die Wirtschaftsprüfung, 61(8), 338-349.

Bittelmeyer, C. (2007). Patente und Finanzierung am Kapitalmarkt - Eine theoretische und empirische Analyse. Wiesbaden: Deutscher Universitätsverlag.

Boutellier, C. (2002). The Evaluation of Intangibles: Advocating for an Option Based Approach. 6th Alternative Perspectives of Finance Conference. Reims Management School.

Brealey, R., \& Myers, S. (2007). Principles of Corporate Finance (9nd Ed.). Boston: McGraw-Hill.

Castedello, M., Klingbeil, C., \& Schröder, J. (2006). IDW RS HFA 16: Bewertungen bei der Abbildung von Unternehmenserwerben und bei Werthaltigkeitsprüfungen nach IFRS. Die Wirtschaftsprüfung, 59(16), $1028-1036$. 
Chiesa, V., Gilardoni, E., Manzini, R., \& Pizzurno, E. (2008). Determining the value of intangible assets. International Journal of Innovation and Technology Management, 5, 123-147. http://dx.doi.org/10.1142/S0219877008001278

Damodoran, A. (1994). Damodoran on Valuation. New York: Wiley.

Drukarczyk, J., \& Schüler, A. (2009). Unternehmensbewertung (6 Edition). München: Vahlen.

Freiberg, J., \& Lüdenbach, N. (2005). Ermittlung des Diskontierungszinssatzes nach IAS 36. Zeitschrift für internationale und kapitalmarktorientierte Rechnungslegung, 5(11), 479-487.

Goldscheider, R., Jarosz, J., \& Mulhern, C. (2002). Use of the $25 \%$ Rule in Valuing Intellectual Property. Les Nouvelles: Journal of the Licensing Executives Society, December 2002, 123-133.

Hanel, P. (2006). Intellectual property rights business management practices: A survey of the literature. Technovation, 26, 895 - 931. http://dx.doi.org/10.1016/j.technovation.2005.12.001

Hoffman, R., \& Smith, R. (2002). An introduction to valuing intellectual property. The RMA Journal, May 2002, 44-45.

IDW. (2005). Institut der Wirtschaftsprüfer in Deutschland, IDW Stellungnahme zu Rechnungslegung: Bewertung bei der Abbildung von Unternehmenserwerben und bei Werthaltigkeitsprüfungen nach IFRS (IDW RS HFA 16). Die Wirtschaftsprüfung, 58 (24), 1415-1426.

IDW. (2007). Institut der Wirtschaftsprüfer in Deutschland, IDW Standard: Grundsätze zur Bewertung immaterieller Vermögenswerte (IDW S 5). Die Wirtschaftsprüfung, 60 (4), 64-75.

Jäger, R., \& Himmel, H. (2003). Die Fair Value-Bewertung immaterieller Vermögenswerte vor dem Hintergrund der Umsetzung internationaler Rechnungslegungsstandards. Betriebswirtschaftliche Forschung und Praxis, $55,417-440$.

Kamiyama, S., Sheehan, J., \& Martinez, C. (2006). Valuation and Exploitation of Intellectual Property. OECD Directorate for Science, Technology and Industry, STI Working Paper 2006/5. http://dx.doi.org/10.1787/18151965

Khoury, S. (2001). Valuing intangibles? Consider the technology factor method. Les Nouvelles: Journal of the Licensing Executives Society, September 2001, 87-90.

Khoury, S., Daniele, J., \& Germerad, P. (2001). Selection and application of intellectual property valuation methods in portfolio management and value extraction. Les Nouvelles: Journal of the Licensing Executives Society, September 2001, 77-86.

Kruschwitz, L. (2005). Investitionsrechnung(10nd Ed.). München, Wien: Oldenbourg.

Lee, W.M. (1992). Determining reasonable royalty. Les Nouvelles: Journal of Licensing Executives Society, March 1992, 124-128.

Lienau, A., \& Zülch, H. (2006). Die Ermittlung des value in use nach IFRS. Zeitschrift für internationale und kapitalmarktorientierte Rechnungslegung, 6, 319-329.

Lintner, J. (1966). The valuation of risk sssets and the stock selection of risky investments in stock portfolios and capital budgets. Review of Economics and Statistics, 47 (1), 13-37. http://dx.doi.org/10.2307/1924119

Loop, D., \& Lipfert, S. (2006). Patentbasierte Unternehmensfinanzierung. Bankpraktiker 12/2006, 594-599.

Mackenstedt, A., Fladung, H.-D., \& Himmel, H. (2006). Ausgewählte Aspekte bei der Bestimmung beizulegender Werte nach IFRS 3. Die Wirtschaftsprüfung, 59 (16), 1037-1048.

Mandl, G., \& Rabel, K. (1997). Unternehmensbewertung - Eine praxisorientierte Einführung. Wien: Ueberreuter.

Mard, M.J., Hyden, S., \& Rigby, J.S. (2000). Intellectual Property Valuation. Financial Valuation Group, Los Angeles. $\quad$ Retrieved $\quad$ December $\quad 9, \quad 2011$ from http://www.gofcg.net/clientImages/21401/ResourceLibrary/ACF12D.pdf

Moser, U., \& Goddar, H. (2008). Grundlagen der Bewertung immaterieller Vermögenswerte am Beispiel der Bewertung patentgeschützter Technologien. In: Schmeisser, W., Mohnkopf, H., Hartmann, M., \& Metze, G. (Ed.): Innovationserfolgsrechnung (pp. 121-179). Heidelberg: Springer. http://dx.doi.org/10.1007/978-3-540-78249-0_5 
Mossin, J. (1966). Equilibrium in a Capital Asset Market. Econometrica, 34, 768-783. http://dx.doi.org/10.2307/1910098

Park, Y., \& Park, G. (2004). A new method for technology valuation in monetary value: procedure and application. Technovation, 24, 387-394. http://dx.doi.org/10.1016/S0166-4972(02)00099-8

Parr, R. (1997). The valuation of patents for licensing transactions. The Licensing Journal, February 1997, 1-7.

Pitkethly, R. (1997). The valuation of patents: A review of patent valuation methods with consideration of option based methods and the potential for further research. Judge Institute Working Paper 21/97, Cambridge. Retrieved December 9, 2011 from http://bus6900.alliant.wikispaces.net/file/view/EJWP0599.pdf

Razgaitis, R. (1999). Early Stage Technologies: Valuation and Pricing. New York: Wiley.

Reilly, R., \& Schweihs, R. (1998). Valuing Intangible Assets. Boston, MA: McGraw-Hill.

Schmusch, M., \& Laas, T. (2006). Werthaltigkeitsprüfungen nach IAS 36 in der Interpretation von IDW RS HFA 16. Die Wirtschaftsprüfung, 59 (16), 1048-1060.

Sharpe, W. F. (1964). Capital asset prices: A theory of market equilibrium under conditions of risk. Journal of Finance, 19, 425-442. http://dx.doi.org/10.2307/2977928

Smith, G., \& Parr, R. (2005). Intellectual Property. Hoboken/N.J: Wiley.

Spadea C., \& Donohue J.J. (2001). Business valuation approaches in intellectual property. Philadelphia Business Journal, 20(31), 11.

Stiroh, L.J., \& Rapp, R.T. (1998). Modern methods for the valuation of intellectual property. NERA Consulting Economists. Retrieved December 11, 2011 from http://www.nera.com/extImage/3864.pdf

Sullivan, P.H. (1994). Royalty rates Conform to Industry Norm. Les Nouvelles: Journal of the Licensing Executives Society, March 1998, 140-146.

Tenenbaum, D. (2002). Valuing intellectual assets. The Computer and Internet Lawyer, 2002, 1-7.

Wirtz, H. (2010). Die monetäre Bewertung technologiebasierter immaterieller Vermögenswerte. Zeitschrift für Controlling \& Management, 54, 224-228.

Woodward, C. (2003). Valuation of Intellectual Property. In:Wild, J. (Editor): Building and Enforcing Intellectual Property Value - An International Guide for the Boardroom (pp. 47-50). London: Globe White Page. 